\title{
Economics without Borders
}

If treated as a single economy, the European Union is the largest in the world, with an estimated GDP of over 14 trillion euros. Despite its size, European economic policy has often lagged behind the rest of the world in its ability to generate growth and innovation. Much of the European economic research itself often trails behind that of the United States, which sets much of the agenda in mainstream economics.

This book, also available as open access, bridges the gap between economic research and policy-making by presenting overviews of twelve key areas for future economic policy and research. Written for the economists and policymakers working within European institutions, it uses comprehensive surveys by Europe's leading scholars in economics and European policy to demonstrate how economic research can contribute to good policy decisions, and vice versa, demonstrating how economics research can be motivated and made relevant by hot policy questions. 


\section{Economics without Borders}

Economic Research for European Policy

Challenges

Edited by

Richard Blundell

University College London

Estelle Cantillon

Université Libre de Bruxelles

Barbara Chizzolini

Università Commerciale Luigi Bocconi, Milan

Marc Ivaldi

Toulouse School of Economics, EHESS

Wolfgang Leininger

Technische Universität Dortmund

Ramon Marimon

European University Institute, Florence and Universitat Pompeu

Fabra-Barcelona GSE

Laszlo Matyas (Lead Editor)

Central European University

Frode Steen

Norwegian School of Economics

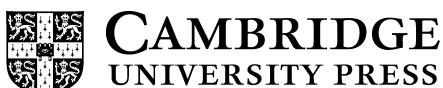




\section{CAMBRIDGE UNIVERSITY PRESS}

University Printing House, Cambridge CB2 8BS, United Kingdom

Cambridge University Press is part of the University of Cambridge.

It furthers the University's mission by disseminating knowledge in the pursuit of education, learning, and research at the highest international levels of excellence.

www.cambridge.org

Information on this title: www.cambridge.org/9781316636398 http://dx.doi.org/10.1017/9781316636404

This work is in copyright. It is subject to statutory exceptions and to the provisions of relevant licensing agreements; with the exception of the Creative Commons version the link for which is provided below, no reproduction of any part of this work may take place without the written permission of Cambridge University Press.

An online version of this work is published at under a Creative Commons Open Access license CC-BY-NC-ND 4.0 which permits re-use, distribution and reproduction in any medium for non-commercial purposes providing appropriate credit to the original work is given. You may not distribute derivative works without permission. To view a copy of this license, visit https://creativcommons.org/licenses/ by-nc-nd/4.0

All versions of this work may contain content reproduced under license from third parties.

Permission to reproduce this third-party content must be obtained from these third-parties directly.

When citing this work, please include a reference to the DOI 10.1017/9781316636404

First published 2017

A catalogue record for this publication is available from the British Library.

ISBN 978-1-107-18515-9 Hardback

ISBN 978-1-316-63639-8 Paperback

Cambridge University Press has no responsibility for the persistence or accuracy of URLs for external or third-party Internet Web sites referred to in this publication and does not guarantee that any content on such Web sites is, or will remain, accurate or appropriate. 